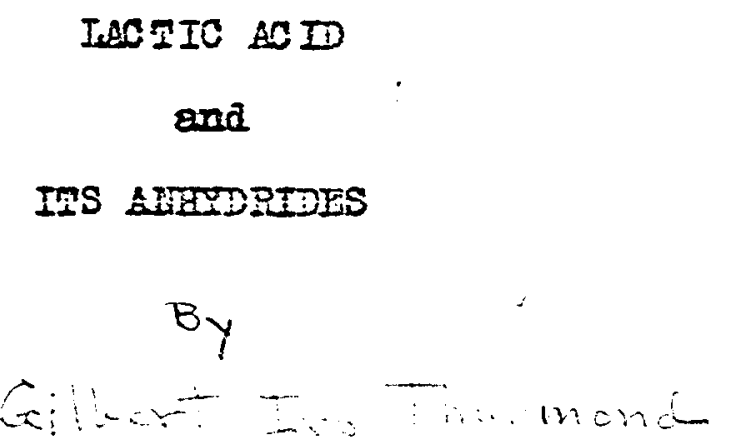

A Dissertation

presented to the Academic Iaculty of the University

of Virginis in candidecy for the destee

of Doctor of Philogophy 


\author{
Pert I. \\ liethod of Analjsis eno Equilibris \\ InTolred.
}

Iage

I. Introanction

1

II. Experimental

(a) Jethod oI analjsis 5

(b) Equiliorion experiments 10

(c) Dialysis experiments 11

III. Treatment of resalts 14

IV. Discassion of resalte 19

Sumary 24 
IACTIC ACID and ITS AHHYDPIDES.

(I) Introanction.

Iactic acie as it appears upon the nastet is usraily prepared by fermenting a solation of fincose mede alizaline vith milk of lime. Although the sermentation does not telke place in a solution containing orer two per-cent seld, a fifteen per-cent solntion goes almost to completion in this Wey, 89 the excess of acti is precipiteted as the calcinm salt and separates. Then fermentation is complete the solution is concentrated, the calcinn lactate filtered off, and the free acid obteined by decomposition with salphorio acid. The acid thro obtained is pare enough for most comercial purposes and is sold aspally as 25 or 50\% aoid. Lactic acia of the U. S. and British pharmacopoeis is prepared by concentrating this acta to a sp. gr. of 1.2 efter certein porlfications. It is supposed to have an acid content of $75 \%$ in adaition to $8 \%$ of anhydrides. The soid is asually sold on the basis of its free acid content as its chief uses are the reduction of chromiam compounds ased es mordants in dreing and chrome tanning, and as a delimer in taming where its value is doe to its ability to keep calcinn salts in solntion and thas prevent harmol precipitation. Lost dealers hold that the aningrides are of no valne for this parpose, however,. . A. Fanst (v01. 10, 
1915 Jorr. Amer. Iea. Ass'n) shors that they are at least partially in error.

Isetic eoid is a syrupy, armost colorless, bitter Iiquid wiscible with weter and alcohol in ell proportions. On being heated in air it loses water enc according to Thompson and Suzuki (rol. 13, 1918 Jour. Amer. Lee. Ass'n) is capable of forming three enhridrides, the first two only appearing in comeraial aaid.

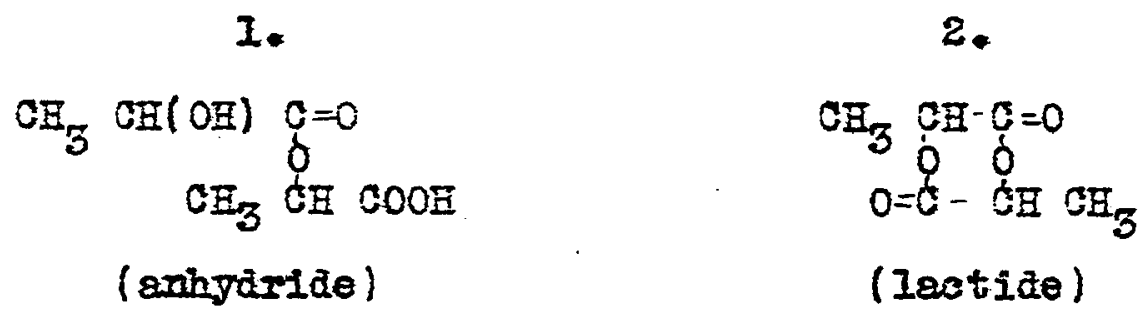

5.

$\mathrm{CH}_{3}$ :

$\mathrm{CH}_{3} \mathrm{CH} \mathrm{COOH}$

(ai-lactic acid)

The literatare containg mang conflicting statements concerning these sabstances. Fisilcenas (Ann. 164-181) says the anhyiride is obtained by heating lactic acid to $150 \mathrm{C}$. In a ourrent of dry air, and describes it as a light jellow, amorphons body only slightly soluble in water bat very soluble In alcohol or ether. Honin (Abs. $\nabla 445$ ) sajs the acid contains no axhydride which is only a laboratorg product. Iieither gives the experimentel date upon which his statement is based. The lactide is usually describoi as a whte oxystalline body almost insolnble in rater bot fatrly goluble in alcobol, ether. or acetone, however, one investigator refers to the brown, morphous 
body above es lactide. Stetements Fizy concerning tive conditloms moder which these substances are formed from lactic acia. Fare (100\%) Iactic soid has been shown to remain unchangod and crystalline for months below $18 \mathrm{O}$. Partial corvergion to anifirides takes place when the acid is allowed to stand at a higher tomperatare. The comercial acid is said to form largely anhydrido then heated at 130-140 0 . Fhich is sabsequentiy converted to the lactide ap to $200 \mathrm{C}$. Where decomposition to forn cerbon dioxide and lactone sets in. Both anhyaride ani lactide are formed when comercial acie is allowea to stand over bulphuric acid at room temperatare. In all cases partial anhydride formation occurs when lactic acid is concentrated by eraporation, and Hislicems points ont that lactide is formed while free acid is still present.

Eydrolysis of both anhydride and lactide vith formtion of lactic acid oceurs fhen either substance is heated Fith water. or treated with alkall or acie. Besson says that the enhydrides are hrarolyzed by an excess of alrali in ten ninutes, and thus are valuatle as delimers.

All of the above statements seem to indicate that the reactions by which anhydride and laotide are formed are reversible, and that condition of equilibrium exists between the three sabstances in solation. Fislicenus states that he believed this to be the case bat attemptea no expertmental proof. The following equations probably express the equilibria involved.

$\begin{aligned} 2 \mathrm{CH}_{3} \mathrm{CHOH} \mathrm{COOH} & =\mathrm{CH}_{3} \mathrm{CHOH} \underset{6}{\mathrm{C}}=0 \\ & \mathrm{CH}_{3} \mathrm{CH} C O O H\end{aligned}+\mathrm{H}_{2} \mathrm{O}$ 
$\mathrm{CE}_{5} \mathrm{CHOH} \underset{\hat{\delta}}{\mathrm{c}=0}$

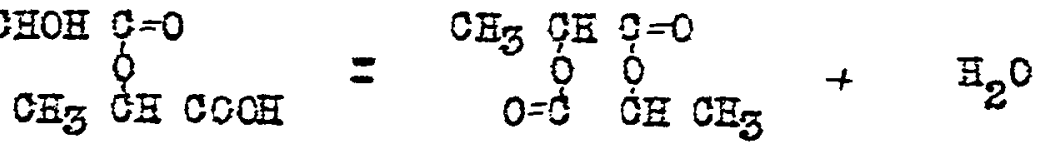

Preliminary experiments soon demonstratea tine existence of a condition of equilibrinm, for upon heating leotic acid of alfferent concentrations in small sealed tubes at 140-I60 C., the concentration of free scia (see below) came rapialy to a defintte valne vhich vas aneltered by further heating, and the same value conld be obtained from mirtures whose original composition varied considerably.

Attempts pere then made to devise a method of analygis by which the concentration of the four constitnents could be determined. mis proved a very different problem. The accepted method of analjo is of comercial lectic acid (AIlen Commercial Organic Anolysis; Jour. Amer. Lea. Ass'n 10. (1915)) consists in (I) titrating a sample vith $0.1 \mathrm{H}$. HaOE, asing phenolphthalein as indicstor: (2) edding an ezcess of standard alkall, and heating on a steam bath for pilteen minates; (3) adding a slight excess of 0.1 II. salphoric acid. and titrating the excess of acid. The first titration neatraIizes the lactic acid present as such and also the free acid hydrogen of the ankjdride (if present). The alkal1 used ap In the second titretion corresponds to hydrolysis of the enhydride salt and of lactide (1f present). From these two titrations the amounts of all three constituents can not be obtained. Ordinarily the alkeli consumed in the first titration is said to measpre the "free acid", and lactic acid is sold on this basis. It is obvions that if the amonnts of lactio 
acid, enhydrile, and lactide in a given semple aro represented bJ $I, I$, and $Z$, respectivelJ, and if (a) and (b) represent the $0.1 \mathrm{I}$. HaOH consumed in the lirst and second titrations respectively, we have the following relations. 11.0 co of 0.1 11. Faoz is equivalent to .009 grs. Inctic aciâ; .0162 grs. aningaride; .0072 zrs. Iactide (hyìroljzeâ).

$$
\begin{aligned}
& a=\frac{Z}{.009}+\frac{Y}{.0162} \\
& \bar{b}=\frac{Y}{.0152}+\frac{Z}{.0072}
\end{aligned}
$$

If ge assame either $Y$ or $z$ to be zero (as is usually done) or determine either $z, Y$, or $Z$ separately (see balow), these two equations saffice to permit the calculation of each constitrent.

\section{(II) Experimental.}

The experiments described belor represent efiorts to deternine by a seperate method some one of the three constitwents. Liter searching the literature no previous fork on methods of ditingrishing betreen the enhjoride and lectiae Fas fonnci to arailabie.

(a) Lethod of analysis.

(I) It wes thought that probably by the use of aifierent indicators two different end points might be jetermined corresponding to the Iree acid and ambdride, regpectively. bat it ras found to be the same in all cases. 
(2) Titrations gere mane at $25 \mathrm{C}$. meking nse of the electrical sonductivity methoa. carve dram by plotting alkali concentrations ageinst conciotivity ralnes showed only one brear, correspondint to the enc point obtaines in (1).

(3) Jiearly all selts of lectic acid are snpposedI insoluble in ether. It res thonght that probaly the snhydride salt woold be insolubie in certain ether-elcohol mirtures.

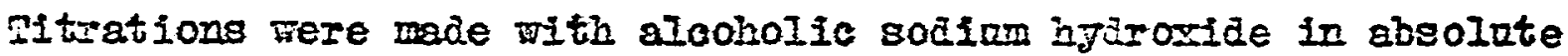
elcohol solution ano other ranging irom an equal amount to four times the arount of alcoinol adjed. Althongh fairly concordant resulte pere oitained the method ras abandoned as impracticable, becanse instead of a crjstalline precipitate a semi-solid mass, Finfch could not be filtered ofs but had to be run off thra a separatory funnel, Fas found to separate from the solution.

(4) Lectic acia was founa to be practicaily insolnble in chloroform while lactide was verg solnble. It was attemptea to extract the lactide Prom a rater solution with ohlorolorm:- zesalts were variable and not reliable, probably are to the inflnemce of the Iree asie present. Mhis ves found also to be the case even thouph the acid wes nontralized first. Similar experiments witi benzene and tolnene provec ansuccessfin for the same reason.

(5) Several selts of lactic acid are recorded as being insolable in ebsolute alcohol at roon temperatare. The magnesiun salt is one and it was attempted to precipitate the acio 四解 megnesinn getate. The resction was slow and 
incomplete. After experimenting vith the acetates and carbonates of several metala, it ras found that gine carbonate reactea readily with lectic acia in alcoholic solution, and epparently with the enkydride, forming insoluble selts, end leaving the lactide in solation. Evidence of the presence of the anhydride salt wes given by the fact an exsmination of the preolpitete shored the presence of noterial uefig af albali on hydrolysis. (The zinc present pas pirst gotien ria of by the mothod given belor.) This reaction ras adapted to the quantitative determination es follows.

The sample for analjsis tro dissolved in absolnte alcohol and a portion corresponding to abont one gram or acid was at once titrated with $0.3 \mathrm{H}$. HaOF, using phenolphthalein as inaicstor, (titration ${ }^{n}{ }^{\prime \prime}$ ). An excess of alkali was then added, the solntion wes heated on the steam bath for Iifteen minuter, gand the excess alkali determined by titration with standard acid, (alkali used, titration $\mathrm{ml}$ ). It was lound that it ras not necessary to include step (3) given in the procedure above. A second portion of the alcoholic solation, equel to that above, was then treated Fith tro grams of zinc carbonate, and was warmed, with etirring, until ploccolent zinenbegan to separate. (usually abont five minntes) The precipitate was Iiltered off nuder subtion, and mashed With absolute alcohol. The filtrate ras erapopated to abont $10 \mathrm{ce}$ and again piltered if further precipitation occored. 20 ce of rater was añded. and the solution rasheated with an excess of standard alkali (to hydroljze the lactide). Anexcess of standard scid was 
then audea. togcther with a Iittie potassiun Lerrocpaniè. and the excess of ecid determined by titration witi standera alsali, (titration " $0 "$ ). The Iollowing notes explein the procedure.

(1) Ireatrent of the alcoholic solution with zine carbonate as inaicated atove gives a filtrate ghich is neutrel fafter the small amount of zinc in solution has been precipitated as ferrooyanide). showing finat both the free acid and exingaride have been neatralized. Since, the lactide is quite soloble in alconol it mast all be present in the lilirrate. anless it has been hyarolyzed by the zine carbonate. sach hydrolysis can hardy have ocorred to ang appreciable extent, since duplicate determinations which had been heated for varying lengths of time gave closely agreeing resalts, which coold hardig be expected if partial hydroljsis were oscoring. Deterninations allaked to stand at room temperatore sor 50 minntes also gave closeit agreeing results, which would seem to indicate that ijdrolysis was not ocewring.

(2) A smell anount of zinc remains in solation after the zinc carbonate treatment. Fiost of this seperates later on evaporation of the solation. The zine is apparently present as Iactide, as it is Ionnd to be nentral and not to use up alkali on heating with an ezcess of sodinm hparoxide and then titrating back with gela. It also separates alfost completely an eraporation of the solution in the cold by a streari of arg alr, pithont causing the remsining golation to become acta, as gronla be the case if it were the anhjaride salt. 
$1 \mathrm{CH}_{3} \mathrm{CECH} \underset{\hat{\gamma}}{\mathrm{C}=0}$

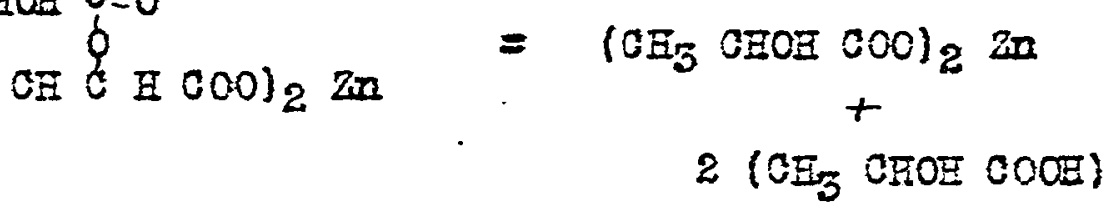

Thas, its presence does not introdnce an error into the lactide determination. It is necessary, however, to remove it from golation, 88 it interieres fith the end point, and the potassian ferrocyanide effects this result. The presence of this zinc has been somerhat dififont to account for. Zine lactate is only slightly solable in alcohol, yet in the experiment a fair anownt of zinc lactate seperates from the alcoholle solution on evaporation. The amount present increases steadily as the lacticie content incresses. The presence of this zinc at first thren some doubt on the accuracy of the ezperiment, as It was felt that it might perhaps be present as the salt of the anhydride, and that it wes being hyarolyzed with the formstion of zino lectate, thus cansing the precipitation daring evaporation. In viev of the lact that the filtrate did not show aciafty and the foldowing experiment, it seems certain that no appreciable anownt of the enhydride salt is present in the eiltrate.

Vreg concentrated mixtrures, prepared by heating comercial acid in a carrent or dry air at $150 \mathrm{c}$. . gare no precipitate when treated with zine carbonate bat a rery large amount of zine lactate was obteined on eraporating the solution. Even on adding relatively large amonts $10.5 \mathrm{gr}$. acid to 1.0 gr. mixtarel of commercial acia to such solntions, the entire emonnt of zinc lactate formed mas found to go into solution. 
It seens possible that this is in colloidal suspension, and that it is peptized by the lactide, thos accounting for the increasingly lerge amounts helà ap as tire percentage of lactide increases. In ang case there seens every reason to beliete that enalysis of the alcholic filtrate measures the lactide falrly accarately, and thas combination of this ralue with the reswlts of the two dswal titrations, as described ebove, permits the calculation of the concentrations of all three constitrents.

In some experiments mitrures of alchohol enc chloroForm (25\%) were used as solvent insteed of pare alcohol, but while less zins appeere in the piltrete in finis case, the resplts were not es easily dopizcoted ss in thentmethod, elthough they geve epprozinately the same vilues. These results are given in table $2(a)$.

(b) Eqailibrinm Experiments.

A series of esperinents Fere carried ont to determine the composition of the equilibrin niztures. To this end smell glags trbes containing dobot five grams or eciá were nearly Iilled, sealer, anc heated for a number (9 to 25) of hours at $155 \mathrm{C}$. (Ereliminary experiments by $E$. R. Eopikins ied shom that tempretare has very little eflect apon the equilibina.) These tabes Fere then cooles and broten, and their contents dissolved in absolute aicohol, the solution being then dilated with elconol to a defintte rolame, and aliquot portions tairen for anglysis as indicater above. Resulto are given in rable $I$. 
The original mixtares were made by mixing somerciel acid, higinle concentrated acid, pare lastide, and veter in such proportione as to gite a veriet. a concentrations, and to approach the ecuilibrim from both siaes.

Experiments we 0750 carried out is which acias of two concentrations vere hegted at 155 and 1000 . Orer a period of two reels. portiong being anglyzed at intervais of ore or tho haps. Wo appreciehle chante oconred stfer the first daj, so only a mean of the analrses are riven. is slight decomposition took place in the trbes heated $5 t 155 \mathrm{C}$. and some of them burst a?ter seterel ders heating. Pesulto are given in Table $2(a)$.

(c) Dialysis kxperinonts.

Por reasons to be discrssor? in the following section, the anhydrice is thonght to probebly be present in colloidel suspension and experinents mere ettempted to prove this point. Earchnent cups af materiels of ifferent porosity iere made, pertially filled with the nirtores, ent plsced in a bath of ranning Fater. Portions were pipetter off and aneryzed at intervals. Zutures of sereral concentrations fere ceed. Ineluding a $\nabla \in$ ry concentrated one prepared by heetinf commercial actí to $150 \mathrm{C}$. If angyiride is present es a colloia, after suficient time, disregeraing hrtrolysis, it elone should remain in the cup end titretions (a) and (b) shonld become egual. It was found that titration (b) Pinally became larger than (a) although both decreased rapidy. Ihis will be aiscussed more fally belon. 
rable I.

Experimental iate.

$\dot{8} \quad \dot{8}$

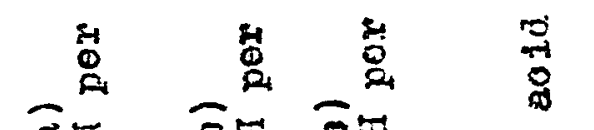

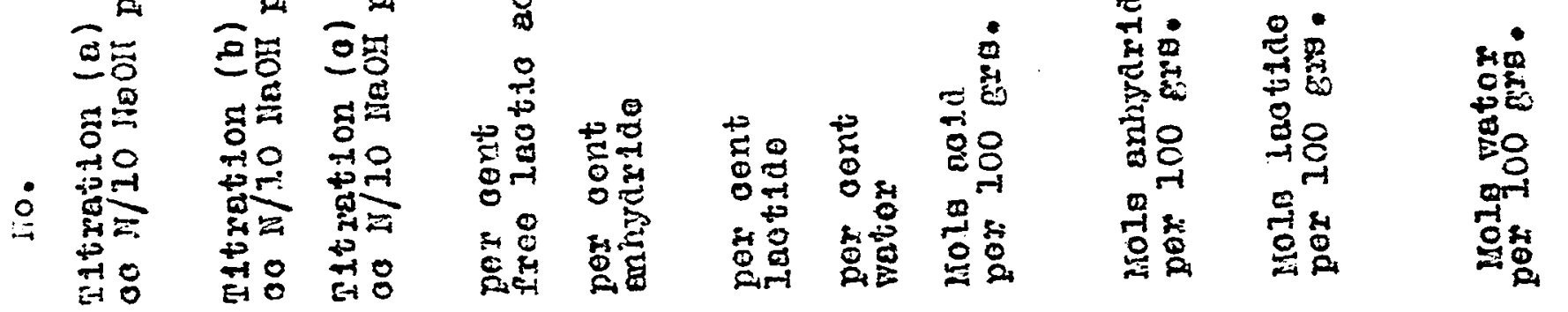

$1 \quad 74.34 \quad 10.39 \quad 6.1465 .145 .88 \quad 4.4325 .55 \quad 0.7016 \quad 0.04240 .0508 \quad 1.418$

$=78.44 \quad 16.20 \quad 10.14 \quad 65.15 \quad 9.83 \quad 7.50 \quad 17.72 \quad 0.7240 \quad 0.0606 \quad 0.0507 \quad 0.486$

$\begin{array}{llllllllllllll}5 & 75.44 & 10.85 & 7.63 & 65.05 & 5.20 & 5.50 & 24.25 & 0.7228 & 0.0521 & 0.0582 & 1.348\end{array}$

$476.55 \quad 10.08 \quad 7.67 \quad 66.76 \quad 3.91 \quad 5.52 \quad 23.81 \quad 0.7418 \quad 0.0241 \quad 0.0585 \quad 1.525$

$\begin{array}{lllllllllllll}5 & 75.14 & 9.56 & 7.48 & 65.98 & 5.05 & 5.39 & 25.58 & 0.7531 & 0.0188 & 0.05743 & 1.421\end{array}$

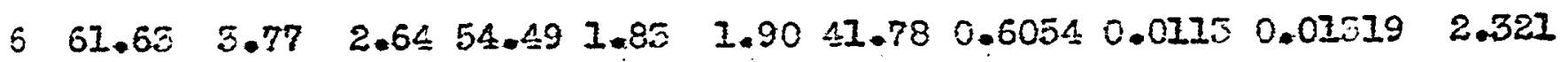

$7 \quad 79.1924 .04 \quad 21.97 \quad 69.47 \quad 3.3515 .8517 .35 \quad 0.7597 \quad 0.0205 \quad 0.110 \quad 0.6305$

$\begin{array}{llllllllllllll}8 & 55.71 & 0.63 & 0.13 & 22.70 & 0.82 & 0.09 & 76.59 & 0.2522 & 0.0051 & 0.000625 & 4.244\end{array}$

$9 \quad-\quad-62.13 \quad 2.46 \quad 3.15 \quad 32.250 .6905 \quad 0.0152 \quad 0.02195 \quad 1.7918$ 
Experimental Irata.

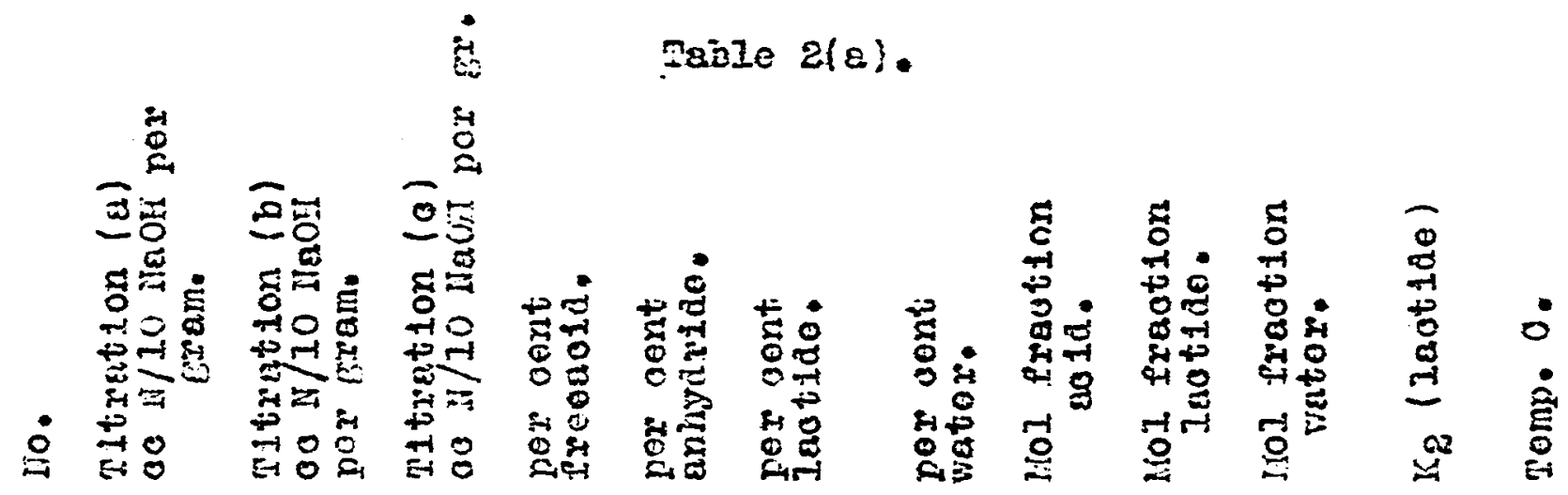

$I(a) 80.50 \quad 18.46 \quad 0 \quad 72.32 \quad 0 \quad 13.50 \quad 14.58 .474 .0545 .471 \quad .0558 \quad 100 \mathrm{C}$. I(b) $80.5017 .95 \quad .8471 .57 \quad 1.36 \quad 12.33 \quad 14.74 .466 .0502 .478 .05281550$. 2(a) $79.9621 .30 .4371 .63 \quad .7014 .8912 .78 .494 .0541 .440 .05091000$. 2(b) 79.6621 .002 .0169 .945 .2615 .6915 .11 .480 .0588 .449 .05I4 155 c.

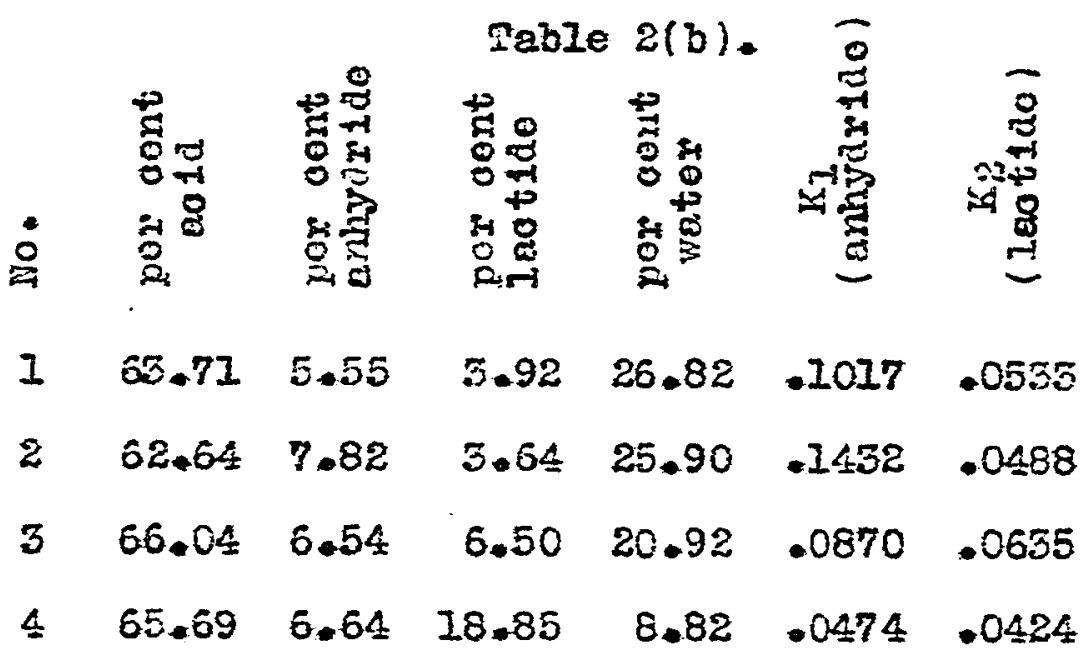




\section{(III) Mreatrent of Zesults.}

Although the experimental aata in rable I incicete clearly tinat a conilition of equilibrion exists betreen lactic aciä. its anhyiricies, and rater, e methenatical analjsis of the conaitions prevailing at equilibrium preserts certain difficnities. In the Pirst plece the and Iytical results are not of the highest aceuracy, at best, and in the second place in so concentrated a sjatem some disficalty is to be expected in representing the activity of the components in terms of the composition of the mixture.

As the nost likely assumption the activity ras taken as proportionsi to the mol fraction, and equilibrium constants were then celcolated from the aste of mable I, expressing the relation between the acia, arifydide, anc vater, and between the acia. lactide, and Fater accoriting to the equations:

$$
\begin{aligned}
& \mathrm{II}_{1}=\frac{\text { mols enhydride } \mathrm{x} \text { nols weter }}{\text { mols } 80 \text { in }}
\end{aligned}
$$

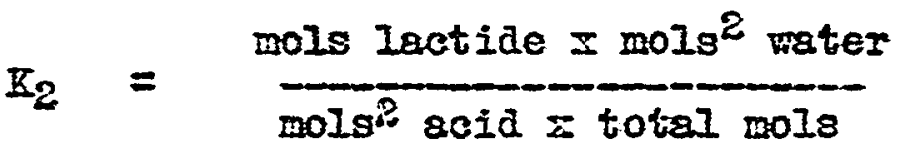

These results are fiten in the second anc third colums os Fable I.

The velues for $Z_{1}$ do not shor any spprcach to constancy, and deteminations phich should be nearly duplicates exhibit an extrentid wide varietion. On the other hand the velues for $\mathrm{Z}_{2}$ show a fair constancy and exhibit 10 dejinite 
trend. This suggests the possibility that the anhgaricie is not present in true solution, but as a collosd, snd therelore not occuring in ang definite anount. The properties assigned to the pare anhydride lend sopport to this idea. Mhus, Thereas lactic acid and the lactiaje are crJstelline boules of delinite properties, the anhydride is described as a "gumm" amorphons material. If the anhyaride is in colloidal suspension it should not affect the equilibring betzeen the components of the homogenons phase, and the data jeble I vere thereiore recalculated on this besis. The mol Irections of acid, lactide, and Fater vere calculated, neglesting the anhjdride present. and valnes for the equilibrium constant rere calculated from them. The results, which are given in Table 3 as E⿰. Show a much greater conetancy than those calcalated on the assumption that the anhydride is present as a constituent of the equilibrian mixture. In order to show how closely the data agree Fith the equilibring expression, the following calculations Fere made. Taking the mean value for $Z_{3}$ as 0.0567 (the mean of the $I_{5}$ values in 817 the tables), we have

mol frac. lactide $x$ mol frace fater

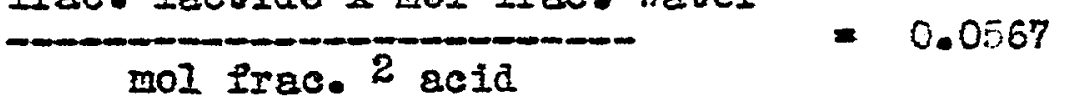

and

mol frac. lectide + mol Irac. acid + mol frec. Hater $=1.0(8)$

If ke assume values for the mol fraction of rater between 0.1 and 0.9, can, by combining equations (7) and (8), calcalate the mol irections of acia and lactide, respectirely. These resulto are plotted in efgure III. Experinental ralaes are 


\section{Table 3.}

Equilibrian Constants.

I0I Zanctions

neglecting anhy?rido.

$Z_{1}$ I2 scid Iastide Tater $Z_{5}$

$\begin{array}{lllllll}1 & 0.122 & 0.0573 & 0.3265 & 0.01433 & 0.6594 & 0.0585\end{array}$

$\begin{array}{lllllll}2 & 0.114 & 0.0515 & 0.4114 & 0.02881 & 0.560 & 0.0554\end{array}$

$\begin{array}{lllllll}3 & 0.085 & 0.0605 & 0.3426 & 0.01810 & 0.539 & 0.0613\end{array}$

$\begin{array}{lllllll}4 & 0.0579 & 0.0573 & 0.3527 & 0.01823 & 0.559 & 0.0579\end{array}$

$\begin{array}{lllllll}5 & 0.0498 & 0.0635 & 0.3347 & 0.02708 & 0.648 & 0.0642\end{array}$

$\begin{array}{lllllll}6 & 0.0715 & 0.0656 & 0.2060 & 0.00415 & 0.790 & 0.0659\end{array}$

$\begin{array}{lllllll}7 & 0.0219 & 0.0477 & 0.4598 & 0.07452 & 0.426 & 0.0539\end{array}$

$\begin{array}{lllllll}8 & 0.338 & 0.0410 & 0.05604 & 0.000159 & 0.939 & 0.0410\end{array}$

$\begin{array}{lllllll}9 & 0.0570 & 0.0588 & 0.2757 & 0.00877 & 0.715 & 0.0589\end{array}$ 
indicated by $x^{2} s$ and their relation to the theoretical velues Fill be discasseả.

These results inicate quite clearly that as far as the free acid, the Iactide, and water are concerned, a definite equilibrium exists between then at $155 \mathrm{O}$. , which is expressed fairly accurately by equation (7) above. Deta, given in Table 2(a). from later experinents on more concentratea mirtures show on en average a lover anhydride valne and give a slighty Iover $I$ value. As indicated above, the velnes of $Z$ can hardIJ be expected to be constant over the vinole range, and, although it shows anto gradnally decrease as concentration increases. it does not vary enough to canse a verg appreciable aifference in the results by taking as the true value a mean of all the values. Thus, the velue 0.0567 , as used in equetion 07 ) above, was taken as the most probable value of $\bar{~}$, and is vell within the experinental error.

Data on experiments at $100 \mathrm{C}$. agree nith those at 1550 . Within the range of acouracy of experiment, so, although indicated as such in the table, thos are plottea with the 155 C. Velloes.

Table 4 gives date on a series of mixtares listed in order of increasing amount of lactide. The $I$ values are calculated on the basis of titration (b) being ased in the hydroljsis of lactide alone, essuming no anhyiride present. The fact that the I values show a definite trend is of interest and il be alscussed. Precentages of acid and lactide ere plotted against total ce's (titrations $(a)$ and $(b)$ t of $0.1 \mathrm{E}$. 
$\operatorname{Tsin} 4$.

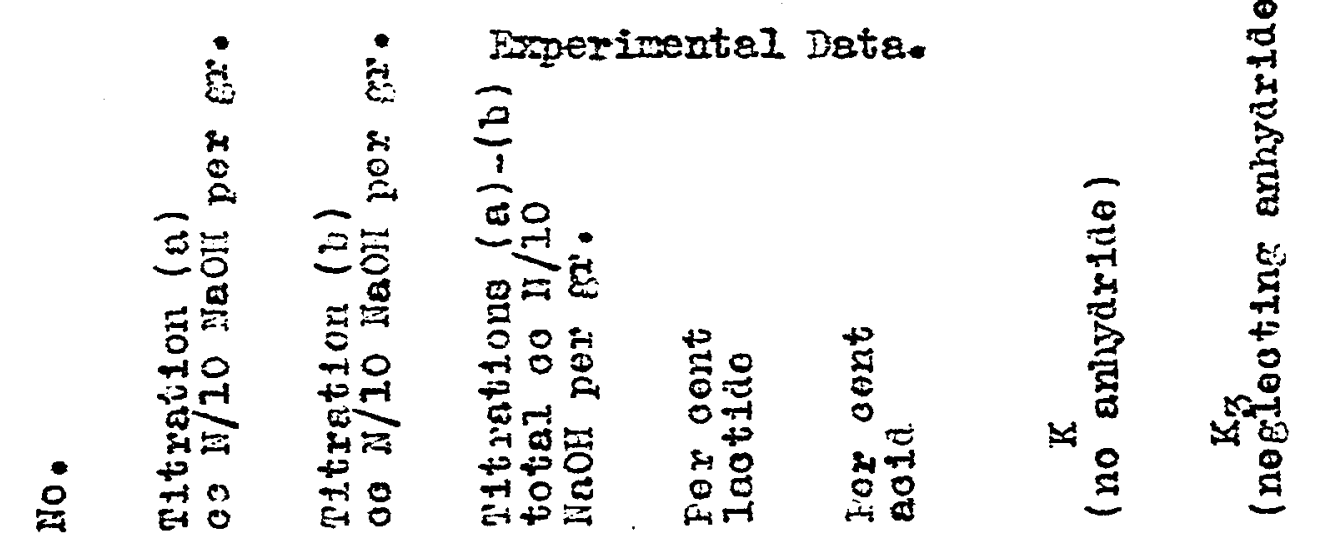

$\begin{array}{llllllll}1 & 25.70 & . .65 & 26.33 & .45 & 25.15 & .1902 & .0410\end{array}$

$245.6 I \quad I .57 \quad 47.18 \quad I .1 \leqslant 4.08 \quad .106 \quad-$

$\begin{array}{lllllllll}5 & 61.63 & 3.78 & 65.41 & 2.72 & 55.51 & .0876 & .0659\end{array}$

$4 \quad 67.04 \quad 4.84 \quad 72.88 \quad 5.4960 .59 \quad .0807 \quad .0564$

$\begin{array}{llllllll}5 & 75.15 & 9.50 & 84.51 & 6.74 & 67.69 & .0755 & .0642\end{array}$

$\begin{array}{llllllll}6 & 78.41 & 16.19 & 94.60 & 11.67 & 70.63 & .0588 & .0554\end{array}$

$\begin{array}{llllllll}7 & 79.22 & 18.22 & 97.44 & 15.15 & 71.36 & .0538 & .0538\end{array}$

$\begin{array}{llllllll}8 & 78.90 & 20.85 & 99.73 & 15.01 & 71.06 & .0513 & .0509\end{array}$

$\begin{array}{llllllll}9 & 79.19 & 24.05 & 105.22 & 17.52 & 71.50 & .0495 & .0539\end{array}$

$\begin{array}{llllllll}10 & 77.04 & 50.74 & 107.78 & 22.15 & 69.39 & .0409 & .0429\end{array}$

$\begin{array}{llllllll}11 & 05.06 & 55.92 & 118.98 & 40.29 & 56.80 & .0169 & -\end{array}$ 
HaOE por gram as pirtore. In preparing this table one or two mixtores that hed apperentig not reached equilibring mere not inclocied.

For reference, the experimental results have been plotted in Pignres I and II as percentages of free acid and lactide present at equilibriom Fith difierent waterconcentrafions.

\section{(IV) Discrssion of Respits.}

As stated abore these results indicate quite clearly that a definite equilibriom exists betroen free acid. Iactia anc water, and that it is not eppreciably affeoted by temperatore. On the whole the nore concentrated mixtures give lactide values corresponding to a somerhat lower average $Z$ value than the dilute mixtares. The assumption that $\underline{X}$ shoold be constant over the finole range of concentrations may probably be in error, and $I$ is actarlly lover at high concentrations then at Iow, as indicated by experimental resalts. Hyirolysis may be greater in the more concentrated mixtures and thas canse hicin acid ralnes, however, this does not seem to plag moh part. as analyses in chloroform at room temperature show no Ereat deviation from those in alcohol, elthough it should certainly be expected to be aut dobn if occuring. Irobably a mean ourve, holding more closely at lover and higher concentrations to theoretical earves plotted from means of the corresponding I values. comes nearer expressing the true values than the theoretical curve as drawn. Fhis wonld certainly more noarly 
conform to experimontai resuits.

It Is interesting to note that comercial acid which has been gtanding for several months strors a I Falue very close to those above.

The behavior of the anhjiride presents something of a parale, and several interesting things are to be noted irom experiment.

(I) It is apparent irom the data in Fable I that the amonntioes not increase regularly as the pater content decreases, and also that it vary considerably with an identical vater content.

(2) The anonnt in concentrated mixtores does not excoed and often is less than that in comercial acil.

(3) The amount at equilibrinm mot be largely determined by the previods histors of the sample, however, the extent of Its fornation seems to be limited.

(4) Concentrated mixtures, prepared by heating comercial scid at $130 \mathrm{C}$. In a current of ary air, show only a small amount of anhyciride, seldom over 4 or $5 \%$ and more often less.

The fact, that the amount of anhydride present boes not folloy any definite lam bnt seems to be determined by the previons history of the semple, sapports the assumption that it is present as a colloid. Tho experiments on coneentrated mixtures were heated for a moh longer perfod than the nore dilute ones, thus probably accounting for the somerhat lorer anhyiride content. ilftares heated at $100 \mathrm{o}$. show a silght $1 \mathrm{y}$ 
lomer average aningoride content than those heated at 1550 . High temperatore mas canse sweh an increage, bot, if so, it is not pronomced enough to say that this is the case. Above certain concentrations the anhyariae seems to be unstable, for mder no conditions ras it possible to obtein a mixtnre contraining more than a fev per cent. The phrsical properties of the mogt concentrated mixtares stadied seem to anpport this view. The anhyaride is deseribed as a gamm, semi-solia

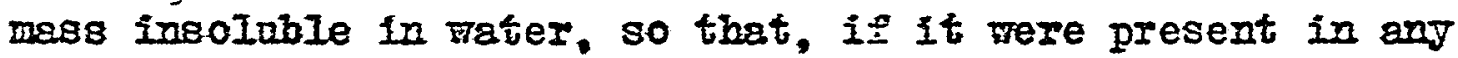
appreciable quantity, we $7007 a$ expect such $\varepsilon$ ooncentrated mixtare to be elnost solid. On the contrary. it ves a fairly mobile solation even at room temperatare and to a large extent solable in cola rater. This seems to indicate that the so called enhydride, obteined by heating lactic acid at $130 \mathrm{of}$ in a corrent of ary air. is rather aconcentrated solution of laotide in acid, ani that increasing the temperatare nerely continnes the same pracess of lactide formation insteed of causing a conversion of eningiride to lactide. or thet the enhyiride is on anstable intermediate produot. is pointed ont above, wonin believed the former to be the case. In spite of the sbove indications, aielysis experiments, attempting to prote the presence of a colloid. vere unsuccessfol. If a colloid vero present, the mixture being. shoold beoome increasingly richer in colloid and the ratio of titration (a) to titration (b) stoold become anity. It mes Found that this retio afd decreese antil it became pnity. but, on continned hyarolysis, it proceened steacily to 8 


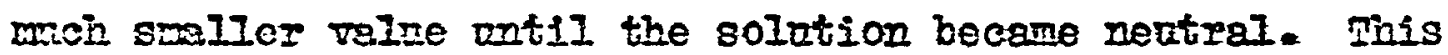
indicates that the lectide difinses moch more 8lotid then the acid, a phenomenon to be expected, bat it nether proves nor aisproves the presence of a colloid. The process tahes several dejs to go to completion, and it mag be that hjdrolysis OI the enhylride occurs sepiloientls rapidis to accont for its aisappearence even if it wore present as acolloid. The actral concentration decreases feirly rapidly et first, and. as hydrolrsis is fond to be very slow in vater solation, the experimental data again woold indeate that the anifiride value is comparatively $10 \mathrm{w}$ in all cases.

It is a rather significant laot that the relne of $z$ cecreases steacily as the lecticie value (calculated on the basis $O f$ no aningdride) increases. Let us consider this in light of some of the things disenssed above.

(1) As has been pointed out, swoh concentrated mirtures would hardly be expected to obey the mass Iall strictly over so wide a range, and if sach is the case, it Foold be expected to carse a steady trend of the $E$ Falnes in one or another direction.

(2) A small, feirly constent amonat of enhydride (and such seems to be the case) wonld here a similar effect. Hhis is seen if we consider the lass lapression

$$
\mathrm{I}=\frac{\text { mols lactide } x \text { nols }{ }^{2} \text { nater }}{\text { mole } \mathrm{s}^{2} \text { acid } \mathrm{x} \text { total mols }}
$$

St 10 ponontrations a small amount of anhydride woold have 
verg little espest on the raver or acid values bat ropla inorease the lactide value (beins sme11), comparativels. Tory considerably, ana thas cause an inorease in $\mathrm{I}$. it $\mathrm{htzh}$ concentretions an equel amont of anhyarfie ronld have verJ Iittle efieat on the raloes of the lactiae and acid, Fhereas, it Fonld canae a comparatsfely large aecrease in the foter ralno and accordingly a deorease in the value of $\mathrm{I}$.

(5) Suppose it is assumed, as tras spggestea above, that the anhyiride salt splits inso a nolecole of lactate and a polecule of sree acla wihich in turn passes into lactate in the pirst titration. Phis ronld not alect the lactide and rater values but canse a constent increase in the acid Value. which ronld, as the acid decreases, become comparatively larger. This means that the denominator is larger hy a constant value, which thro hes an increasingly greater effect on $I$ as the mixture becomes more dilnte. LccordinglJ. the downtara trend of $E$ should be in the opposite direction.

(4) If it is asramed that two molecoles of the anhydride salt hyarrolyzew-to tro nolecules of lactete and a noleculo of lactide, the eflect is opposite to that in (3) end explaing the trend of $\mathrm{I}$. However, suoh a change seems very unizely.

Ixobebiy the best explangtion of this gradual deorease in the value of $I$ Fith the increase in concentration is that it is dine to the conined elfects of (I) end (2). likely angmented by an increase in the hjoirolysis 89 the concentration of lactide increases. At any rate, the anhydride 
being small, acia and lactide valnes calculated on the besis of no eninglride being present are not greately in error with the experimental data, and probably are ritinin one or two per cent of the aetual Falnes. For this reason the percentages or lactide and free acid, on this basis, have been plottec

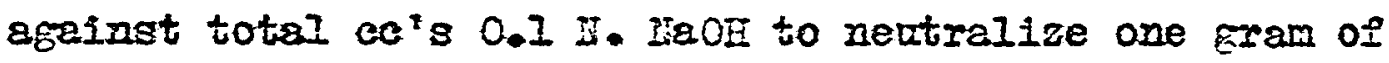
material fifgure IVt. This shovid be neeful in obteining a close approwimation to the equilibrian values by one titration. The date cover practically the whole range.

\section{Surmery.}

(I) A mothod of ansigsis has been devised for determining ail four constituents of mixtores of lactic acid, lacíc anhyiride, Iactide, and vater.

(2) Phis method has been spplied to the analjsis of mixtures of these constituents heated for some time at 155 and 1000 .

(3) The results indicate that a definite and calcalable equilibriam condition exists betreen the lectic acid, lactide, and water.

(4) Temperatore has been shown to have no eppreciable esfect upon the equilibrin.

(5) The anhydride is alpeys present in reletitely small amounts. There are indications that it is present in the colloldal state, homever, attempts at experimental proof have been onsuccessial. 
(6) Regalarity in the variation of $\mathrm{K}$, assuming no eningiride present, has been pointed ont and possible zegsons disansed. 


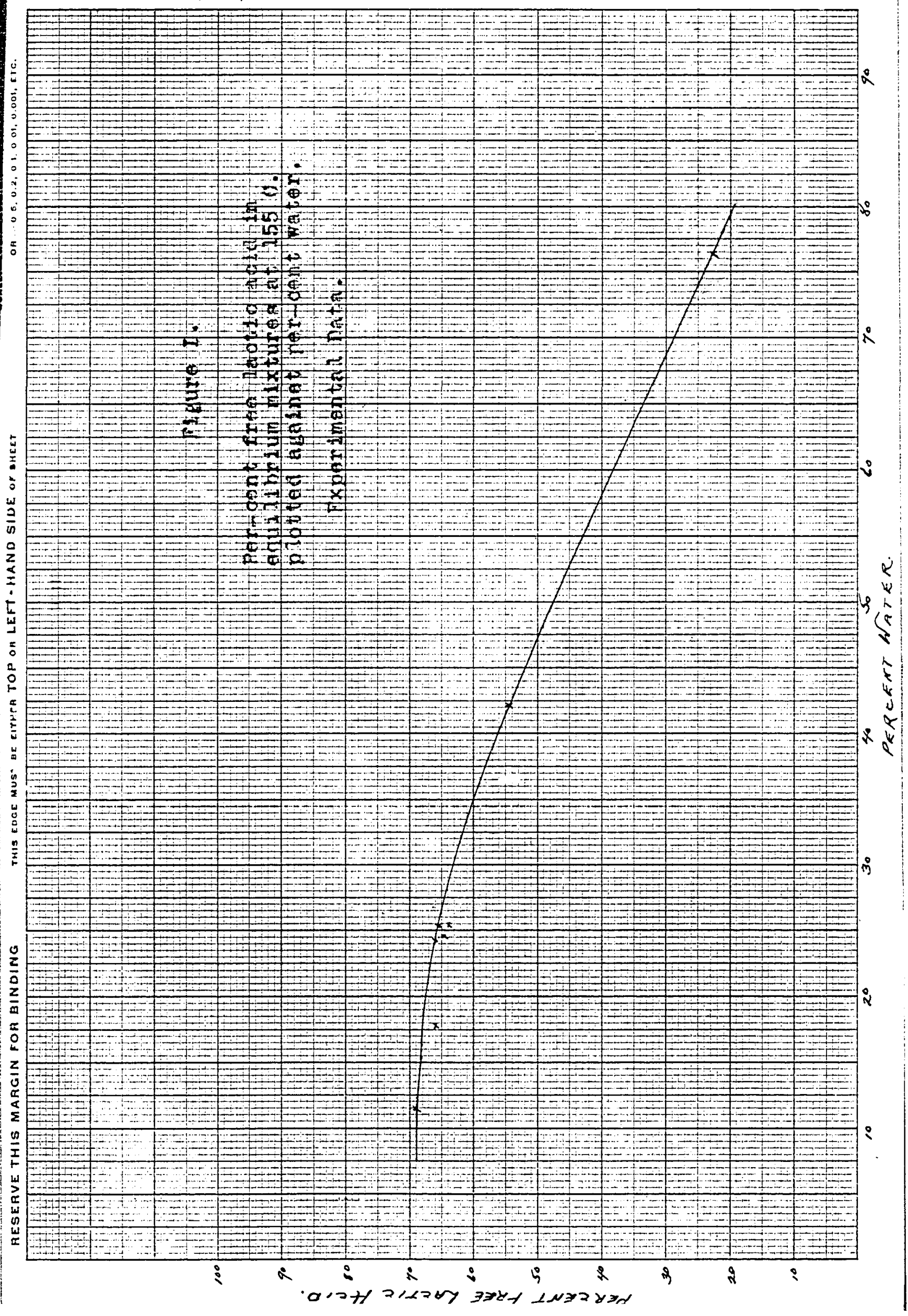



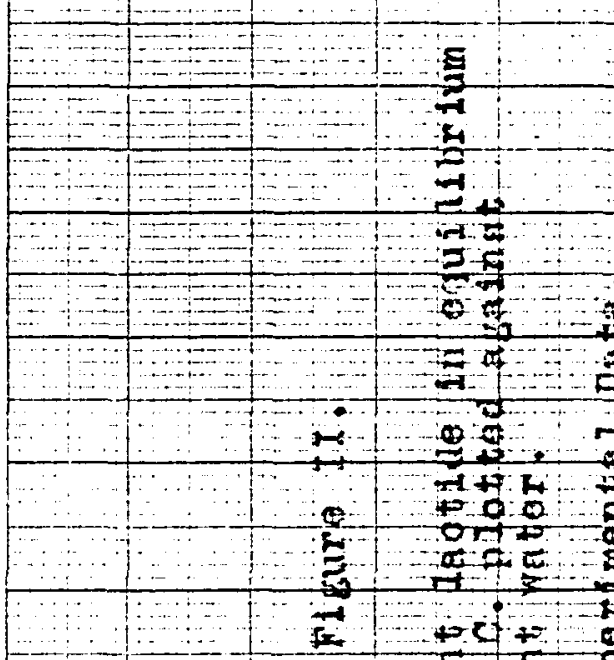

$\frac{1}{2}$

9

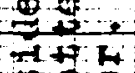

00

क्षे

$\rightarrow+i+1$

$\cos \theta$

17

$+=$ 


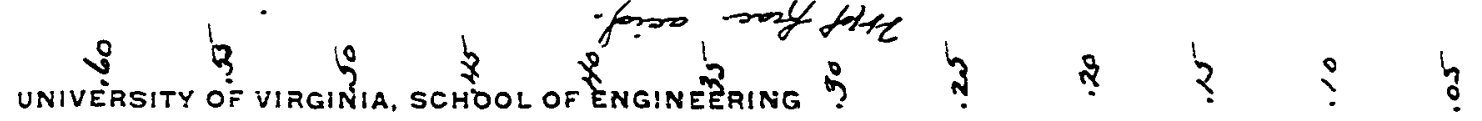

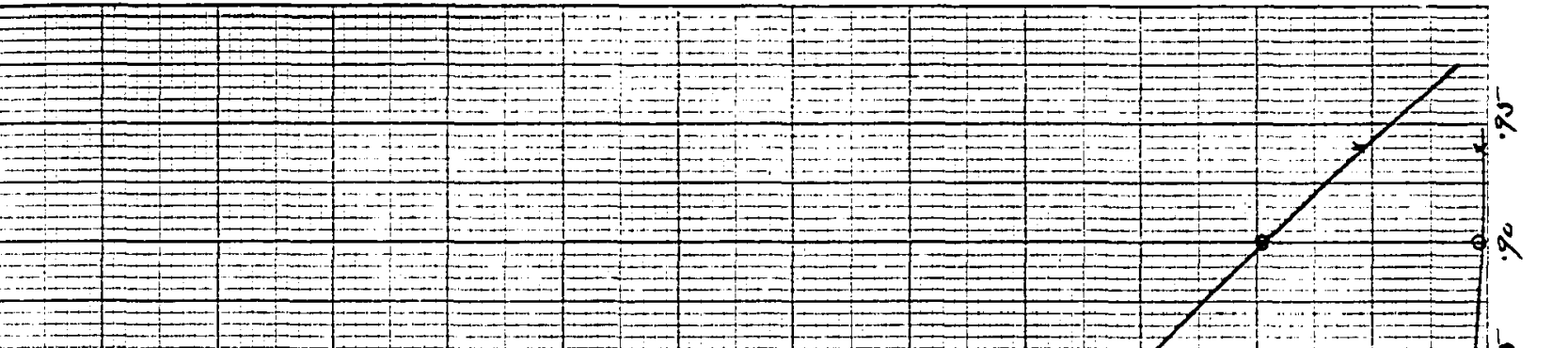

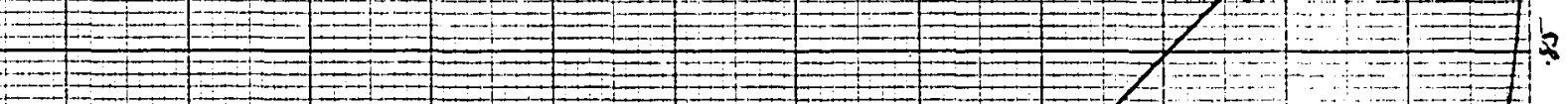

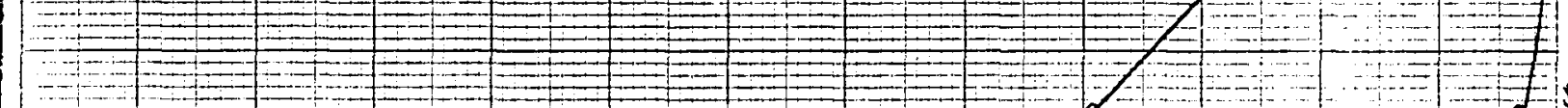
$-$

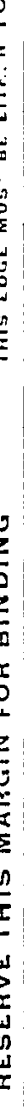

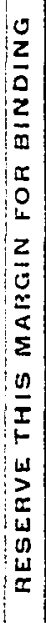

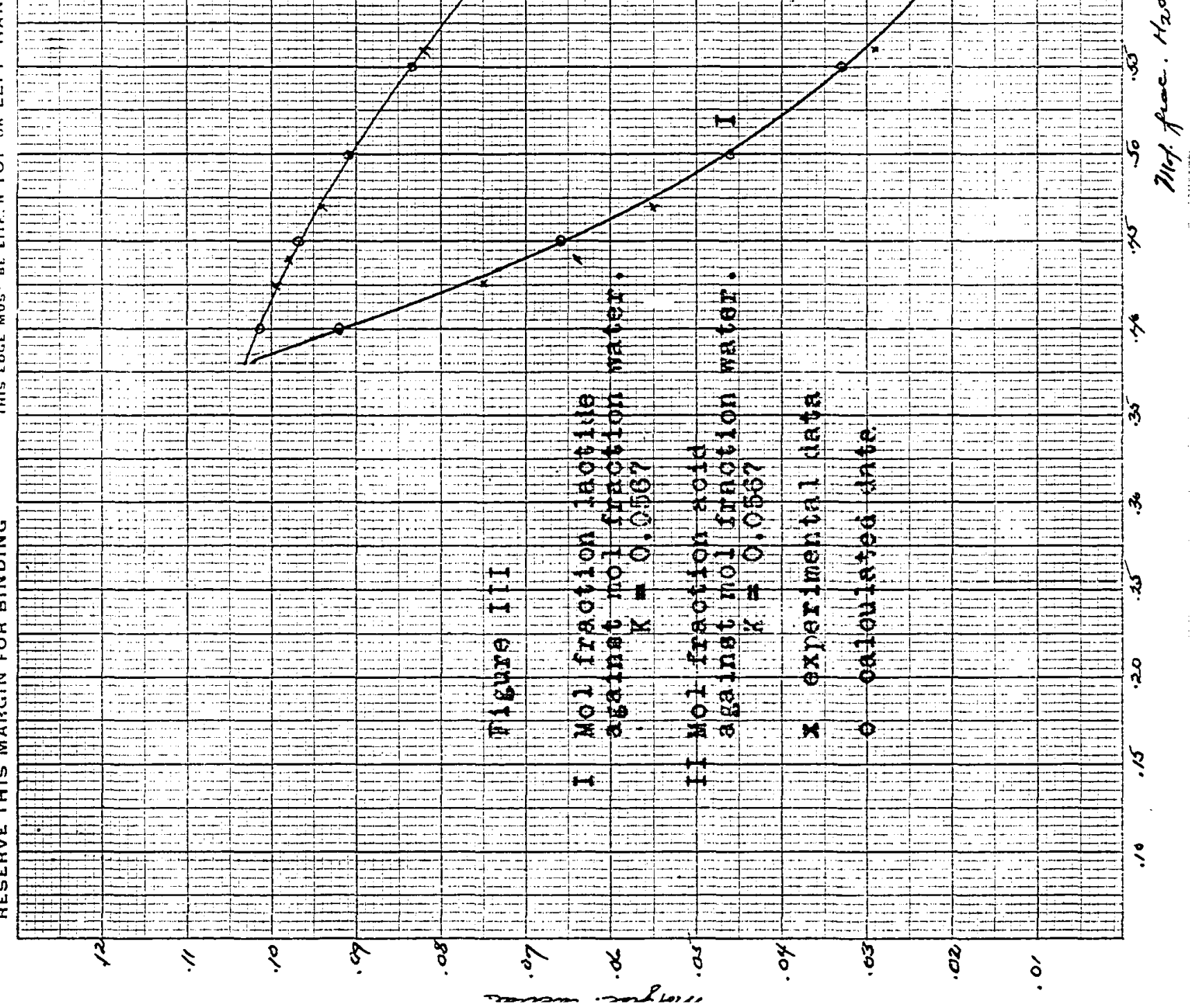




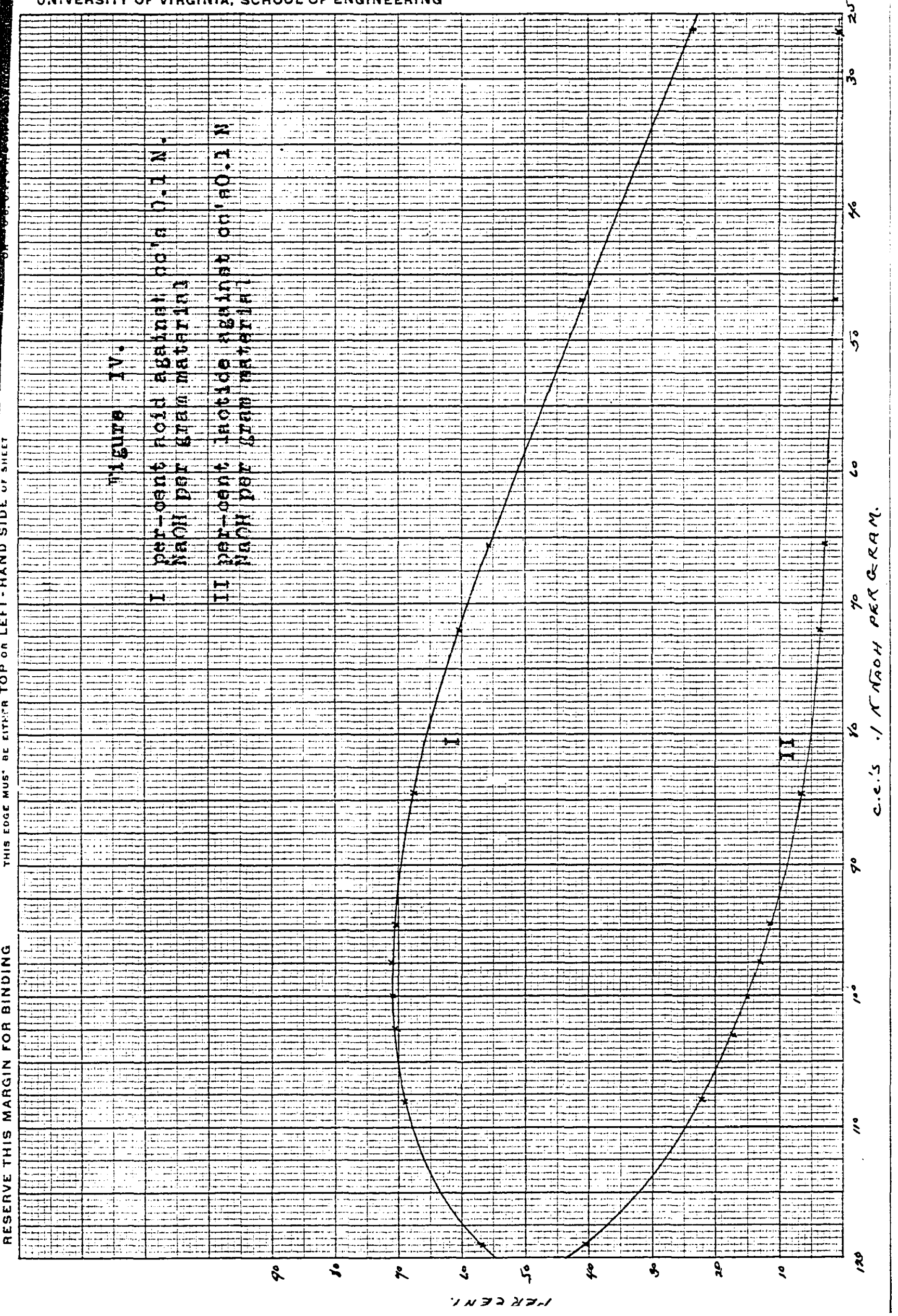




\section{Fart II.}

Rate of Isctide Fornation and Distillation of Iactic Acla at Ion Iressures.

I. Introduction

Yaze

II. Esperimental

27

(a) Rate of regation

28

(b) Diatiliation op Iactíc aoid

28

31

III. Bearing of the resulis on mothods of proification of lactio aeta.

36 Acimowledgnent. 


\section{(I) Introdnction.}

In the concentration and digtillation of lactic acid It has long been recognized that lectide and anhjuride formbtion represents $a$ loss to the rannfactarer, and various mothods of preverting this loss have been patented srom tine to time. howerer, none proving entirely satisiactory. This failure hes probsbig been largely due to a lack of knoviledge of the exact mechanism and conditions of the formation of the anhydrides. In light of the asta presented above certain principles seem reasonably clear.

(1) Iratide is formed from lactic acid by a reversible reaction which proceeds, at elevated temperatures, Iather rapialy to a definite equilibriom represented by the equetion

mol srac. lactide $x$ mol irac. 2 vater nol irro. 2 acid

I being IIttle affacted by temperatore.

(2) If lactic acid is concentrated at temperatures sufficientig high for the rate of reaction to be feirly repia. lectide Hill be formed as the rater is removed. The amount of lactide in equilibrium increases very rapialy when the vater content becomes $10 \%$, bat nothing is zenorn as to the rate at which such a change takes place at various temperatures. 
(3) The mechanism of the lass of lectic acia by enhydride formation is mah less clear. In all cases the amotont of enityidide present hes been found to be smell, never being over $5 \%$ and mon less than this in highly concentrated solntions. Thus, in concentration or alstillation, where ve Fill be dealing with very concentratea solntions, the loss by anhyciride formation can be neglected.

The purifiestion or lactic acid involves uswally two steps, concentration and distillation. It is inpossible to make ang intelligent suggestions as to aroiding loss of free acid in lactic acid proiflcation by these processes, onless some data are available on (I) the vapoz-pressarecomposition curres, and (2) the rate of lactide formation at different temperatares. For this reas on it was thought to be worth while to carry ort some experiments on the distillation of lactio acld at low pressures and the rate of lactide formation et temperatares near those involved. Although the data are by no means complete, the time being too short for a very exhansty study. they show qualitatively what the chenges are and permit certain fairlJ intelligent suggestions as to methods by which lactic acia can be purified.

\section{(II) Experimentel.}

\section{(a) Rates of reaction.}

From one or tro preliminary aistillation experiments it was seen that, if purification was to be effectea by dis- 
tillation at a pressure of half a centimeter or less, the temperatare rould be between 90 and $100 \mathrm{C}$. This being the case, water wea natwally shosen as the most saitable bath in Fhich to carry out experinents on the rate of lectide formation, and. for this reason, rost of the data is given at $100 \mathrm{c}$. One run was made in a bath of boiling tolnene (110 O.) to see hor great the effect of a ten degree increase in temperature vooldac on the rate. Ohe same mixture was also Iun at 100 0.1

\& 25 cc erlenmejer flask Fas fitted jith a pressure top and about tro-thirds Pilled rith the ecid miztwre. Fis Was inmersed in a mast of tater hested nader reilax, and one gram samples pipetted off and analyzed at intervals as inalcated, Analjses vere made for acio and lectide according to the usual mothod, essaming no anigiride present. The dats are given in rable I, and certein rans exe expressed graphically as inaicated in Figare I. In Bigure II the rate of change of the percentege of acid of a concentrated solution at room temperature with time in dags is shown. The solution Eas

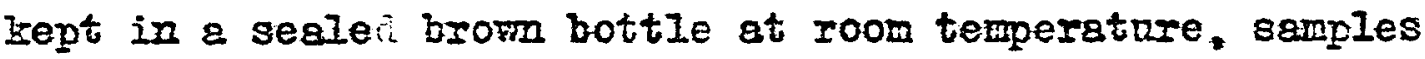
being aram off and analyzed at intervals as shom in the table. As can be seen Irom Figare IV pert I the mixtare is still lar above the equilibrino condition bnt proceeding rather rapialy torara it. Whis experiment shows the uselessness of concentrating lactic acid ebove $7 \bar{i}$ or $80 \%$, if it is to be stored for any length of time. If the acia is to be kept in storage ior six months or longer, the oxtimem concen- 


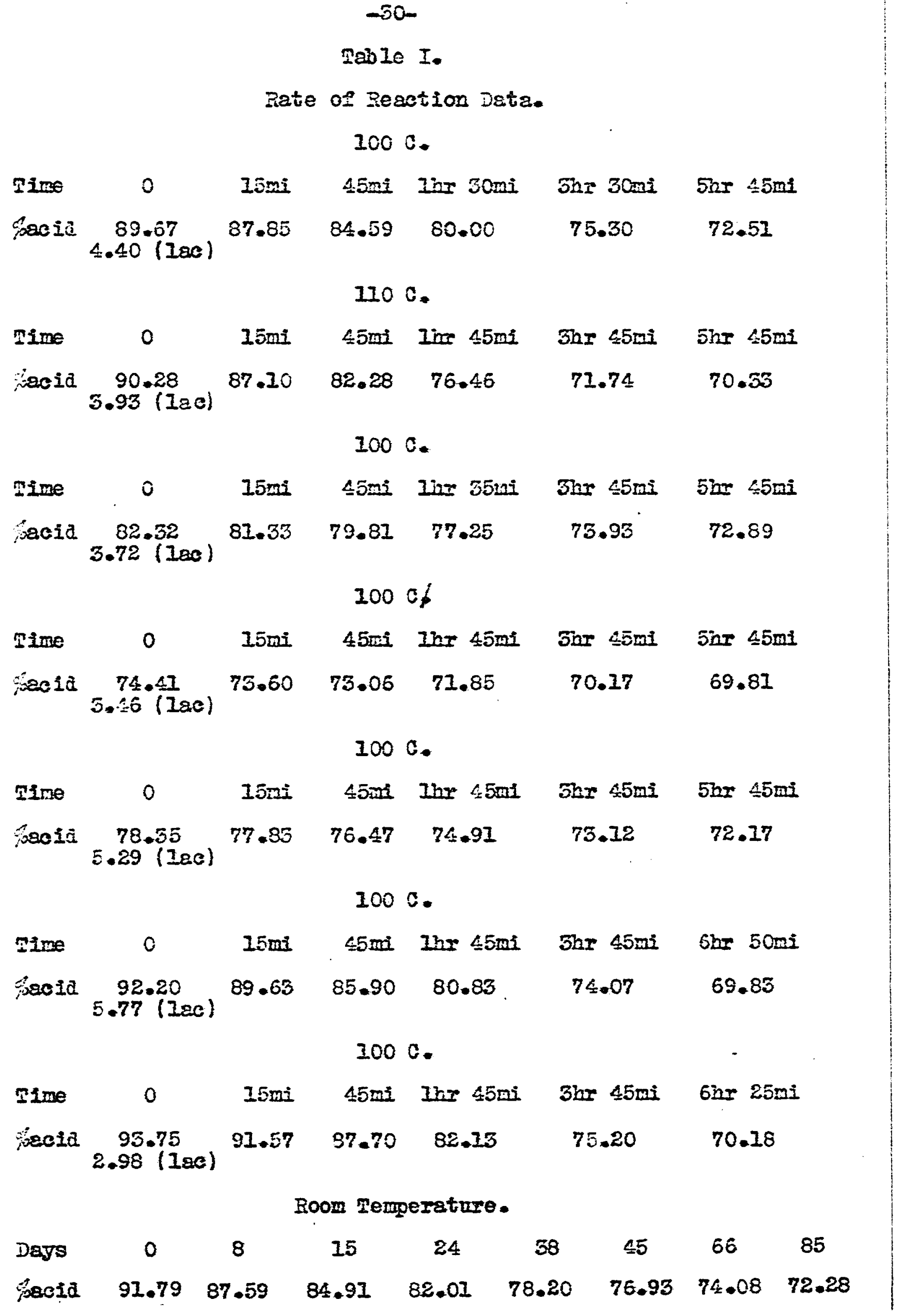


tration to aroja loss by lactlae formation is about $80 \%$, as seen Prom Figure IV part I. At this concentration the mirtare contains $70 \%$ acid end $10 \%$ lactide. Above this concentration the acid content begins to slowly decrease and the lactice to rapidis increase.

Theoretically very littlo can bo arawn from the dete of Figare I. The reaction does not seem to se one of the first order, es thenlogarithms of the concentrations plottea against time ão not gire a straight line. Eorever, the effect of the counter reaction nas not taien into consideration, so this is not certain. Curves III and IV show that the rate is hardy doubled by a ten cegree rise in temperature, as is asually approzimately the case. But, the increase is oper one half, so it is highly desirable to hold the temperature as 10 as possible in aistillations. From carves I and II it does not seem that the rate of lactide formation is increased by a slightly greater initial lactide content. The curves are almost parallel orer the whole range. Bonging speaking. for the approxinate concentratione intolved in distillation 198\%, $10 \%$ of the acid is converted to lactide in two hours, so that, as $\pi 111$ be seen leter, this is about tine time limit for a alstillation.

(b) Distillation of lactic acid.

The rate of lactide fornation is onappreciable at ordinary temperatures, but, as is seen from experiment, becoses quite appreciable around $100 \mathrm{O}$. For this reason, it is necessery tihat, if purification is to be effected by distillation. 
the distillation be carried ont at as low a temperature as is possible. Thus, the experiments pere sarried out at pressures as 100 as it seened reasonable to expect to maintain in practice.

Commercial acta was dilnted to $25 \%$ with distilled wer and heated under rellex mtil the equilibring state Fas epprouineted ( 15 to20 hours), the extting the leotide content to a minimom. The reat acid solution tas then distilled from a $500 \mathrm{ce}$ Plast of the clafsson tJpe, the neck and side arm of wich pere insulatea with a thich coat of magnesia, thrn a conienser jecketed vith ice froter, and collected in a Plesk imnersed in an ice bath. The distillation Plask wes heated by being imersed in an oil bath up to the magnegla coating. The vacum was maintained by a water pump until the distillation temperature reached $50 \mathrm{C}$. . the fater pamp then being replaced by a cenco-Helson racuam pamp. A closed mercury monometer, connested to the system between the

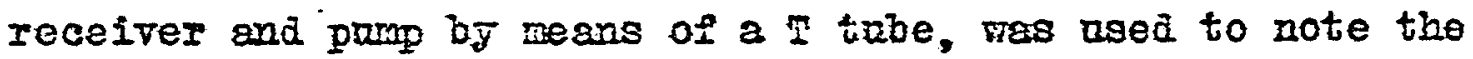
pressure. In experiment 4 the receiver was arranged so that fractions conla be aramn off mithont allawing the pressure to Ifse, and a capizlary trobe was inserted in the distillation flasix. so that samples conld be drawn off by suction after allowing the presswee to rise only a sew centimeters. In the ather experiments the system was brought to atmospheric pressure to change receivers and pipette samples from the residae.

The data of experiments $\frac{\hbar}{6} 3$ and $\frac{f}{f} \leq$ are complete enough 
DIstillation Date.

桴.

Temp. Eresswre weipht ol Dist.
Socid

Iretide mater

Dist.

Resiäze

409.7858

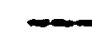

25.43

74.16

$50 \mathrm{c}$.

16

275.5

7.50

.14

32.56

8.8

Eeter

72.56

1.58

25.86

600.

16

25.5

V. S. 2012

$90 \mathrm{C}$.

36

1.6

7. s. acia

$92.6 \varepsilon$

5.75

3.59

$120 \mathrm{~S}$

16

$\$ 7.9$

88.83

2.81

8.36

51.32

47.27

I. 41

1500.

$10 \mathrm{~mm}$

15.0

75.36

74.73

9.95

27.54

70.81

1. 84.

it.

$435.5 \mathrm{gm}$.

$\cdots$

25.00

.44

74.56

witer

70.96

1.12

27.92

.43 acia

90.26

1.77

7.96

15.0

51.92

.34

47.74

95.74

4.39

1.87

96.64

1.79

1.57

55.19

42.04

2.77 
Distifigtion Data.

\begin{tabular}{|c|c|c|c|c|}
\hline \multirow{2}{*}{ Temp. } & \multirow{2}{*}{ Zressure } & B. & \multicolumn{2}{|c|}{$\begin{array}{l}\text { Mocia } \\
\text { Moctide } \\
\text { preter }\end{array}$} \\
\hline & & & Dist. & בesinge \\
\hline$-\infty$ & - & $418.0 \mathrm{grs}$ & - & $\begin{array}{r}24.66 \\
.47 \\
7 \leq .87\end{array}$ \\
\hline 226. & 14 & 180.8 & .99 acia & $\begin{array}{r}44.52 \\
.73 \\
54.95\end{array}$ \\
\hline $30 \mathrm{c}$ & 14 & 42.5 & .21 acia & $\begin{array}{r}55.75 \\
.95 \\
45.32\end{array}$ \\
\hline $38 \mathrm{c}$ & 14 IER & 57.0 & .27 acia & $\begin{array}{r}72.90 \\
1.22 \\
25.08\end{array}$ \\
\hline 500. & $14 \mathrm{~mm}$ & 28.9 & $1.0020 i a$ & $\begin{array}{r}94.52 \\
1.86 \\
3.62\end{array}$ \\
\hline $\begin{array}{l}\text { to } 1700 . \\
\text { (rapiang) }\end{array}$ & 14 & 2.7 & $\begin{array}{r}8.49 \\
.22 \\
91.29\end{array}$ & $\begin{array}{c}90.55 \\
7.39 \\
2.06 \\
\text { no anhyaride }\end{array}$ \\
\hline to 118 & $14 \min$ & 20.5 & $\begin{array}{r}82.61 \\
1.64 \\
15.75\end{array}$ & $\begin{array}{r}82.88 \\
14.87 \\
2.25\end{array}$ \\
\hline 1180 & 14 & 33.2 & $\begin{array}{r}89.76 \\
3.23 \\
6.95\end{array}$ & $\begin{array}{r}60.63 \\
38.13 \\
1.24\end{array}$ \\
\hline to 1600. & $14 \mathrm{~mm}$ & 24.5 & $\begin{array}{c}76.77 \\
20.01 \\
3.22 \\
\text { aningiride }\end{array}$ & $\begin{array}{r}23.13 \\
76.77 \\
.10\end{array}$ \\
\hline
\end{tabular}


$-35-$

Distillation Data.

\begin{tabular}{|c|c|c|c|c|}
\hline \multirow[t]{2}{*}{ Tezup. } & \multirow[t]{2}{*}{ Eressure } & $\tilde{\bar{\xi}} 4$ & \multicolumn{2}{|c|}{$\begin{array}{l}\text { iacid } \\
\text { Tractide } \\
\text { Fatex }\end{array}$} \\
\hline & & & Dest. & Pesidre \\
\hline- & - & $417.0 \mathrm{grs}$ & - & $\begin{array}{r}25.75 \\
.42 \\
75.85\end{array}$ \\
\hline $20 \mathrm{c}$ & $14 \mathrm{~m}$ & 241.0 & 2.85 acid & - \\
\hline $30 c$ & $14 \mathrm{mon}$ & 55.0 & .28 2cia & $\begin{array}{r}85.16 \\
2.06 \\
12.78\end{array}$ \\
\hline 350 & $14 \mathrm{~mm}$ & 15.0 & .55 ecia & - \\
\hline $90 \mathrm{C}$ & 7 Int & 1.0 & .89 se1d & $\begin{array}{r}89.20 \\
7.64 \\
3.16\end{array}$ \\
\hline 970 & $3 \mathrm{sm}$ & 22.5 & $\begin{array}{r}24.05 \\
1.59 \\
4.56\end{array}$ & $\begin{array}{r}79.36 \\
25.58 \\
2.06\end{array}$ \\
\hline 970. & $3 \mathrm{mon}$ & 15.5 & $\begin{array}{r}94.20 \\
2.41 \\
3.39\end{array}$ & $\begin{array}{r}66 \cdot 43 \\
31 \cdot 94 \\
1 \cdot 63\end{array}$ \\
\hline 970 & $5 \mathrm{~mm}$ & 26.2 & $\begin{array}{r}91.75 \\
3.95 \\
4.50\end{array}$ & $\begin{array}{r}49.71 \\
49.24 \\
1.05\end{array}$ \\
\hline & & :5. & & \\
\hline- & - & 416.0 & $-\infty$ & $24 .-3$ acid \\
\hline to $32 \mathrm{c}$ & 15 एक & 284.5 & .188012 & $-\infty$ \\
\hline $104 c$ & $5 \mathrm{~cm}$ & 92.0 & $\begin{array}{r}75.09 \\
2.95 \\
22.96\end{array}$ & - \\
\hline to $160 \mathrm{c}$ & $5 \mathrm{~mm}$ & 19.0 & $\begin{array}{r}72.82 \\
25.50 \\
1.58\end{array}$ & - \\
\hline
\end{tabular}


to permit a fairly complate eraphical presentation of the vapor-pressure-composition changes. For experiment the the changes in corposition for both distillete and resiane vith the temperatore are plottea (ligare III). Whe changes in the distillate of experinent ore similarly plotted in Pigare IV. Altho the data on the residue are not complete, It can be seen that the curves Fonld be similer to those in Pigare III. During the first part of the distillation pare nater distills over, the temperature remaining constant. (The acid in this part of the distillate is aue to banping.) When the veter content has become very low, the temperature Iises rapidy to the boiling point of lactic acio and almost pure acio olstilis over, the temperatare remaining constant. ithen the ratio of acid to lectide has reached a value corresponding approximately to that for equilibrinm condition (reed from Iffore I part Il, the temperatare begins to rise and a distillate considerably richer in lactide distills over, the temperatare gradaally rising to 150 to $160 \mathrm{C}$. The percentage recovery vill be discusser in the following section.

Bearing of the Eesults on 泟故ods of Porification of Iretic Acid.

From the data above it can not be predicted what effect imparities will have on lactide formation in the distillation of crude lactic acid, as the experiments were cerried ont on meterial conforming to U. S. E. specifications. Eowever, assuming that they vill heve $e_{A}$ anc neglecting the srasl amont of aninguride formed, there is reasonibly good 
gromi for certein specalations conceming possibie methods $0 \cong$ parification.

If the experimental date are indicative of what joule taike place on a comercial scale, the followine shoula be trae in a distillation.

Asspming thatinge start with a solotion containing 75: water, that has been heated to bxing the constitrents to equilibring, there Hill be about $24 \%$ acid and only 0.2 to $0.4 \%$ lactide present. If the pressure is nor lept at I4 me, the Bater will aistill over between 20 ana 500. with practicelly no formation of lactide. As seen from ex-

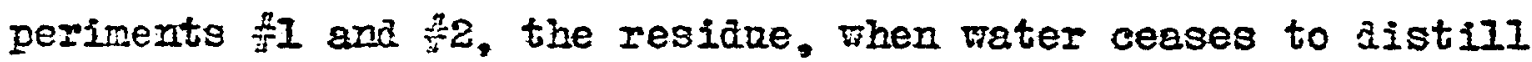
orer, Fill contain about 93 to $94 \%$ acid and 4 to $5 \%$ lactide. If the pressure can now be lowered and held at 2 . $96 \%$ acid Will distill over antil the ratio of acid to lactide in the residne corresponde to that of the equilibrinm condition (experiment 2 ). At this point approsimetely $80^{\circ}$ of the acid Fill have distilled over. Abore this temperature no lactide will be formea , but a mixtare of lectide and acid vill aistill oter batil lactide alone remeins in the residne, which fill aistill betreen 140 and $160 \mathrm{C}$.

Experiments $\frac{5}{4} 2$ and $\frac{5}{4} 5$ mere run somerhat nore rapials then the others and more nearly indicate the possible recoverg. In experiment $\frac{f}{* 2} 2$ the recovery ras $90 \%$ acid, the lactide not being distilled over. In experiment the recoverg $78 \mathrm{~s} 85$ acid and about $12 \%$ leotide, a small amount of Isctide being Iast due to condensation taking place in the flask and receiver. 
If these distillates rere now dilated to the point where the cortsin 70, os acid, that of experinent fit roold contain less than the ancunt of lactide required by the equilibrium and experiment 75 onj rery sl1ghtl more. mas, is in practice the pressare cen be mantainea at 2 to $3 \mathrm{~mm}$, it should be possible to poris lactic acia by an intermittent distillation process, obtaining a good recovery and an acid tiat has the composition of the comercial acid now on the market. If a more concentrateà ecia vere desireă for imedate ise, it might possibly be prepared as follows. By the process above en 80 to $85 \%$ vield of $95 \%$ acid can be obtained, leaving a residue of the composition corresponding to the equilibrin condition, nemely, abont $45 \%$ lactide. This residce is found to be still fairly mobile when cold. so could verg easily be

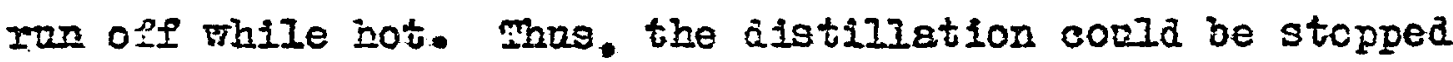
at this point and the residue ron off, allated, hydrolyzed, and again distinled. A namber of residaes conld be collected and ran together, thas moing the totel loss very small. Processes in which lactic acid is distilled with a current of inert gas pader pressure havenpatented. The use of steam at 200 pressures was thought of as another possibility. serving the dovble purpose of carrying the acid over and keeping the lactide content at a low relue. It is seen from the experiments that the rater content arops to a very Iow ralue before acid begins to distill orer, and there is no intermediate period there the rapor pressure of the acid is appreoisble as compared to that of the rater, thus naking 
it impossible to obtein a noderately concentrered acid at

a lower temperstare. Though the edmission of a smell amount of stean during the distillation might help the Jield to e slifint extent, it does not seen Ifkely that it wonld enter into tho reaction and prevent the formation of lactide. It has been suggested that purification of lectic acte ffight best be accomished by some meano of peporizing the scid repidis, thes cutting domn the time for lactide formation. It seens that it shoold be possible to distill off the veter, as above, at $14 \mathrm{~mm}$, and to then spray the acid onto a series of plates or into an etmosphere hot enorsh to imnediately volatilize both acid anc lactide, thas ottaining a distillate of approsimately the seme composition. There is one evident objection to this process. Any resiane formed poula be solia or more likely "gumy" and nould be very aifisicolt to remove from the still. For this resson a continnong aistillation process does not seen to be rerg reil adapted to the puripication of lactic aclà. of course, these are onIt speculations Irom a practical viempoint end further experinents aro neceseary to determine theis value as a comercial process. However, they do not scen to be taken entirely from the air. 


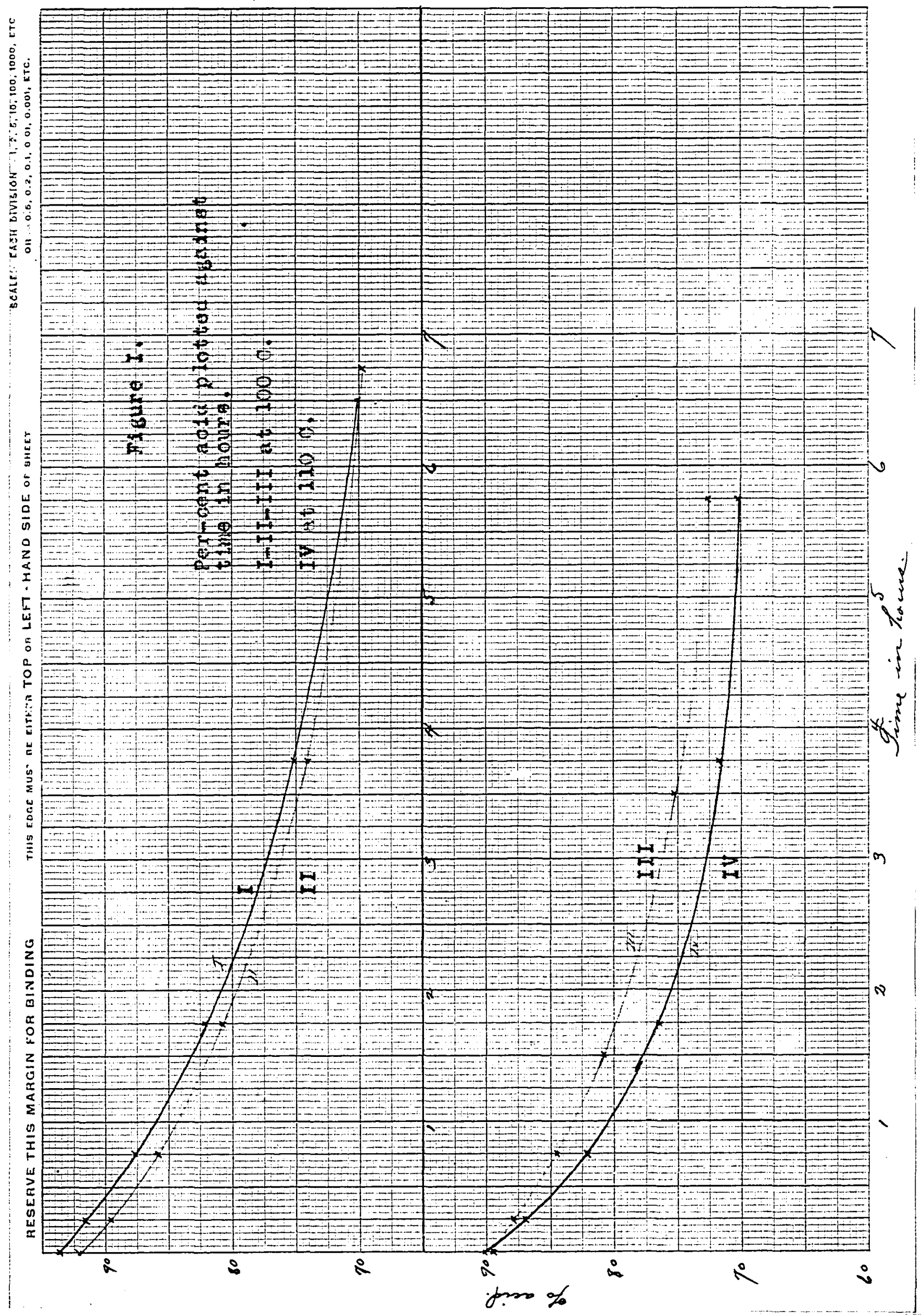




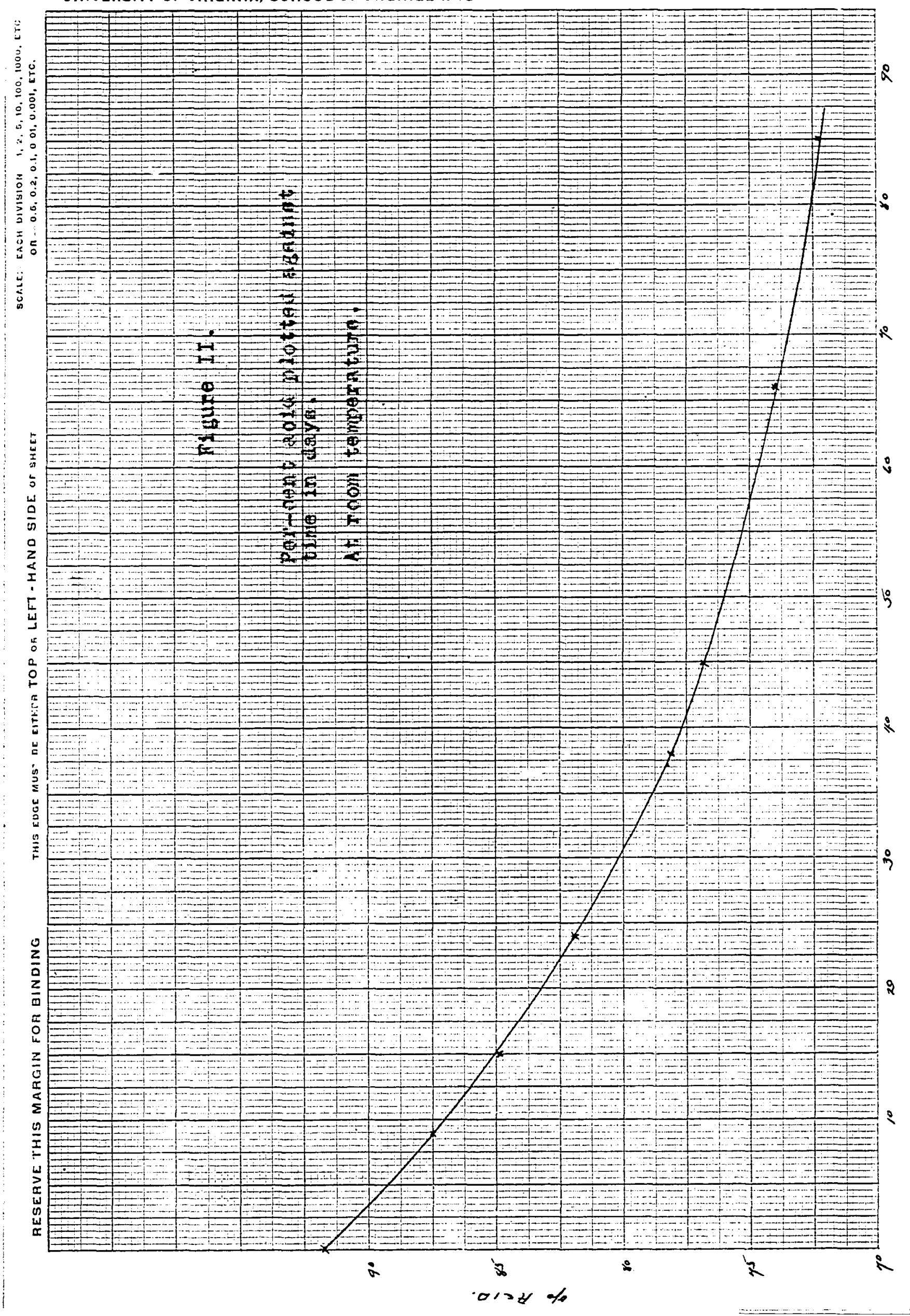


UNIVERSITY OF VIRGINIA, SCHOOL OF ENGINEERINE

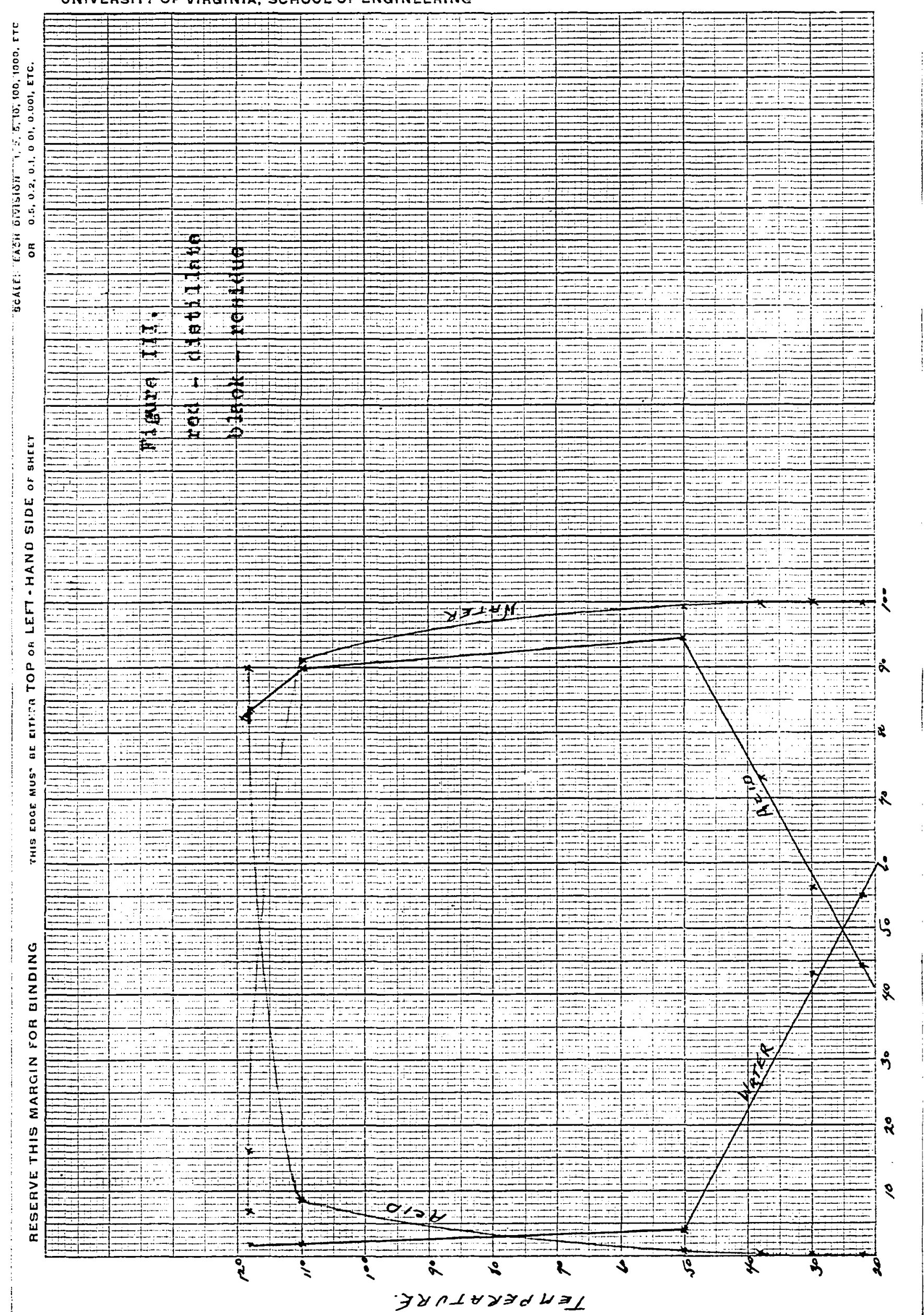




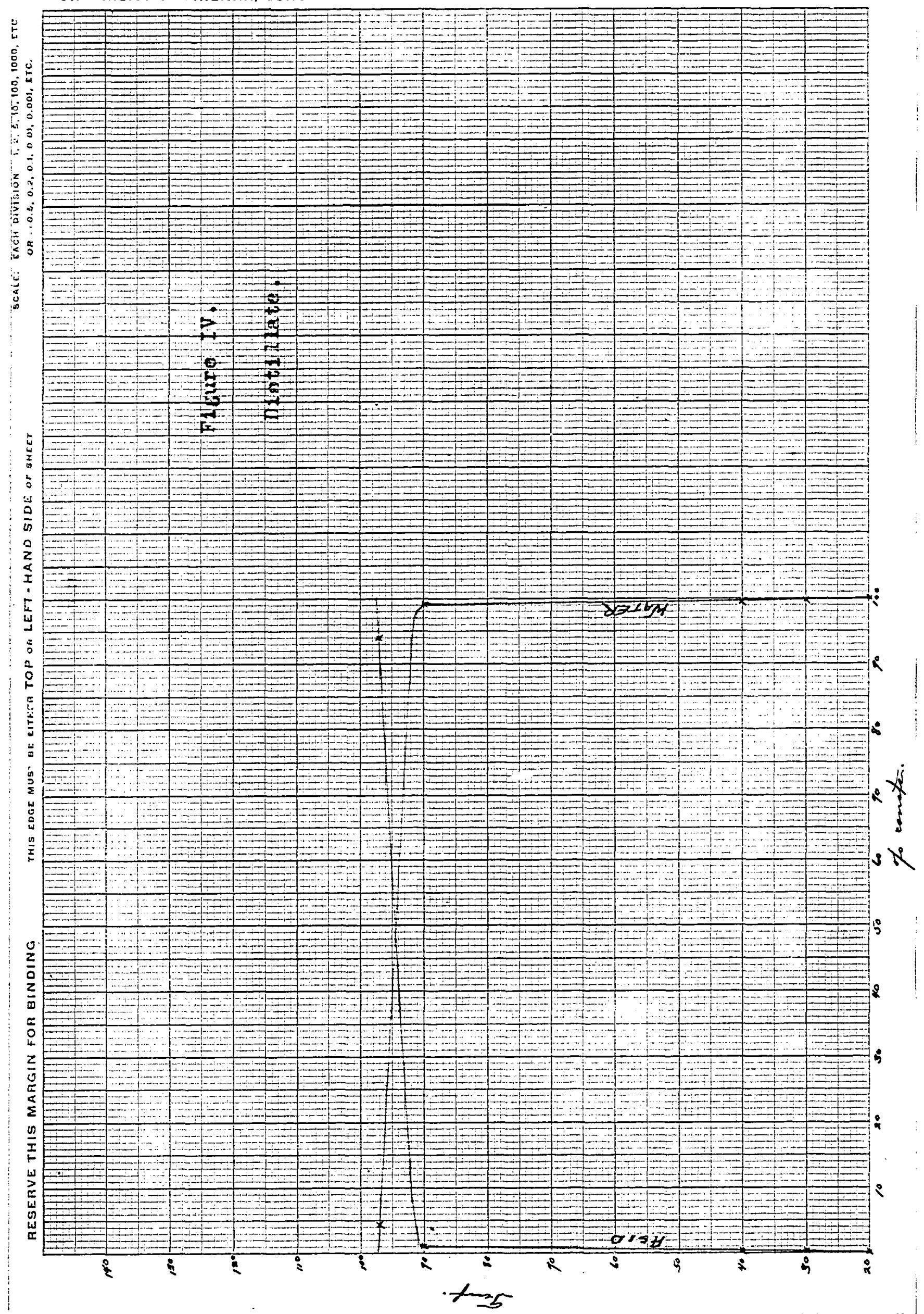

